\title{
Applying a Reservoir Functional-Zone Paradigm to Littoral Bluegills: differences in length and catch frequency?
}

Reservoirs exhibit gradients in conditions and resources along the transition from lotic to lentic habitat that may be important to bluegill ecology. The lotic-lentic gradient can be partitioned into three functional zones: the riverine, transitional, and lacustrine zones. We measured catch frequency and length of bluegills (Lepomis macrochirus) captured along the periphery of these areas (i.e. in the littoral zone of each functional zone) for four small reservoirs in Southeastern Ohio during the summer months of three years. Catch frequency differed between zones for two reservoirs, but these differences were not observed in other years. There was no relationship between reservoir zone and either standard length or catch frequency when the data for all reservoirs were pooled, but we did observe a bimodal length distribution in all reservoirs. A combination of ecological factors including inter and intraspecific competition, predation intensity, management practices, limnology, and assemblage complexity may be mitigating bluegill distribution and abundance in reservoirs. Therefore, a functional zone (categorical) approach to understanding bluegill ecology in reservoirs may not be appropriate. 


\section{Nathan Ruhl*}

2 Department of Biology, Rowan University, Glassboro NJ 08025

3 Holly DeAngelis, Abigale M Crosby, and Willem M Roosenburg

4 Department of Biological Sciences, Ohio University, Athens Ohio 45701

5 *Corresponding Author: Ruhl@Rowan.edu 


\section{Introduction}

Bluegill (Lepomis macrochirus) exhibit ontogenetic habitat shifts that coincide with shifts in foraging behavior in natural lakes. After hatching in the littoral zone, young-of-year bluegill migrate to the limnetic zone to feed on zooplankton (Werner, 1969). Once a larger body size has been attained, bluegill return to the littoral zone and feed opportunistically amongst macrophytes. After several years feeding in the littoral zone, larger bluegills shift back to a diet of zooplankton and move freely between the littoral and limnetic zones (Mittelbach, 1981). Shifts in bluegill diet and habitat use may be a result of a trade-off between maximizing foraging efficiency while minimizing predation risk (Werner and Hall 1988). However, Wildhaber and Lamberson (2004) suggested an alternative hypothesis based on a hierarchical model of tradeoffs between prey availability and temperature in lakes. Regardless of the specific cause of the shift in bluegill habitat use (direct selection pressure via predation versus indirect selection pressure from prey/habitat availability), it is an effective life history strategy (reviewed by Werner and Peacor, 2003).

The success of habitat switching as a life history strategy for bluegill may depend on a number of factors. For instance, basin morphometry may lead to differential recruitment success of bluegill amongst natural lakes where maximum depth, percent littoral area (Tomcko and Pierce, 2001), and lake surface area (Tomcko and Pierce, 2005) have all been linked to recruitment success. Littoral bluegill abundance is positively associated with habitat features such as the availability of woody debris (Newbrey et al, 2005), and native macrophytes (Theel and Dibble, 2008). Another important factor is the availability of zooplankton (Garvey and Stein, 1998); lakes with low productivity or high turbidity have low epilimnetic phytoplankton abundance which reduces zooplankton and thus decreases bluegill recruitment .(Stein et al, 1995). High abiotic turbidity in the photic zone is normally driven by physical processes such as wind mixing and flooding but also can be influenced by sympatric species that resuspend sediment (e.g. gizzard shad; Vanni et al, 2005) resulting in both direct and indirect densitydependent effects on bluegill recruitment via alteration in prey availability and/or capture success (Aday et al, 2003; Shoup et al, 2007). Indeed, protracted spawning by bluegill (Garvey et al, 2002; Kaemingk et al, 2014) may be an adaptation to offset density-dependent effects caused by competition for prey (Partridge and DeVries 1999; Michaletz, 2006; but see Leonard et al, 2010).

Reservoirs exhibit gradients in the relative area of littoral vs. limnetic habitat (Thornton, 1990), zooplankton community composition (Bernot et al, 2004), and a suite of environmental variables including turbidity (Thornton, 1990) and available nutrients (Kennedy and Walker, 
39 1990) vary along the lotic-lentic transition. Reservoirs can be divided into three functional zones

40 based on these gradients (Figure 1): the fluvial zone is the shallow unstratified portion that is

41 heavily influenced by flooding and where well-mixed epilimnetic water is in direct contact with

42 sediments, the transitional zone is weakly stratified and less influenced by flooding or sediment

43 resuspension, and the lacustrine zone is the stably stratified lake-like area (adapted from Kimmel

44 et al, 1990).

45 Interpreting the ecological dynamics of reservoirs in the paradigm of functional zones

46 along the lotic-lentic transition has been regularly applied to organisms that are at the whim of

47 hydrologic conditions (reviewed by Ruhl, 2013a), but to our knowledge has not been explicitly

48 assessed in relation to more motile species such as fish. Additionally, the functional zonation

49 paradigm for reservoirs typically describes open water rather than along the shoreline (littoral

50 zone), despite the fact that differences in the mixing regime in open water may directly influence

51 factors such as nutrient availability along the periphery. Because bluegill ecology is intimately

52 linked to the conditions and resources in the limnetic as well as littoral zones, the functional zone

53 paradigm may be particularly relevant and yield insight into broadscale differences in their

54 ecology within reservoirs (i.e. both along the lotic-lentic gradient and between the littoral and

55 limnetic zones). Specifically, we predicted that size and catch frequency may vary among

56 functional zones because of differences that affect bluegill recruitment (i.e. their suitability for

57 growth and reproduction, see above). We sampled bluegill abundance in the littoral zone

58 throughout four different reservoirs to assess their use of the lotic-lentic transition, (in multiple

59 years in some cases) during July and August .when stable thermal stratification is normally

60 strongest and therefore differences among functional zones may be at their peak.

\section{Methods}

62 Study sites

63 We sampled Dow Lake, Lake Hope, Lake Snowden and Fox Lake. These four reservoirs

64 are located in close proximity to one another in the unglaciated hills of Southeastern Ohio and are 65 managed by units of the Ohio Department of Natural Resources (Figure 2, Table 1).

66 Dow Lake (Stroud's Run State Park) is used primarily for recreation, but also to mitigate

67 flooding of the Hocking River downstream of Athens, Ohio. This reservoir was filled during

681960 and the watershed is composed of minimally disturbed hills, woodland, and open fields.

69 Throughout the reservoir, the littoral zone has been modified via the felling of shoreline trees and 
70 addition of brush piles to coves during the early 2000s (Greenlee, District 4 ODNR Biologist,

71 pers. comm., 2010).

72 Lake Snowden was filled during 1970. The reservoir previously supplied drinking water

73 to the surrounding community, but currently is used for flood control, hatchery water supply, and

74 recreational activities. The watershed consists of rolling hills, agricultural fields, and woodlots

75 while the shoreline habitat includes submerged trees, overhanging brush and abundant submerged 76 macrophytes.

77 Fox Lake was filled during 1968 and the watershed is composed of rolling hills, 78 agricultural fields and woodlots. High sedimentation rates in the riverine zone have resulted in 79 poor angler access to the reservoir and, consequently, submerged macrophytes were removed 80 during the mid-1990's in order to increase flow and accessibility to the riverine zone (Greenlee, 81 District 4 ODNR Biologist, pers. comm., 2010). These efforts have not been successful in 82 improving angler access and dredging to manually remove sediment is impractical for this 83 reservoir. watershed is composed of mature second growth forest scattered with abandoned pit and shaft coal mines. The reservoir has abundant invasive emergent macrophytes (primarily fragrant water lily, Nymphaea odorata) mixed with a variety of other emergent and submerged macrophytes around the periphery.

Bluegill are not regularly stocked into any of the reservoirs (Table 1). Rainbow trout

91 All four reservoirs are stocked yearly or in alternating years with channel catfish (Ictalurus

92 punctatus, mean $221 \mathrm{~mm}$ ) during the Fall. Lakes Snowden and Hope are stocked with saugeye

93 (Sander canadensis x Sander vitreus, mean 31.5mm) every year during the Spring. Fish are

94 normally stocked into the reservoirs in close proximity to the boat launch, meaning that stocked

95 fish are introduced into the riverine zone at Dow Lake and Fox Lake, the transitional zone at

96 Lake Snowden, and the lacustrine zone at Lake Hope.

\section{Sampling regime}

98 The reservoirs were sampled using shore-line traps during three different years, but only

99 Dow Lake and Lake Hope were repeatedly sampled (Table 2). Trapping was conducted during 100 July and August in all years, but the number of weeks during which trapping occurred varied by

101 year. All trapping was conducted using a randomized block design both within and among 102 reservoirs, thereby minimizing the likelihood of a temporal effect among reservoirs or reservoir 
103 zones within a given year. Sampling methods were in accordance with Ohio University IACUC

104 protocols and Ohio Department of Natural Resources Permit \#464.

105 At each trapping site, pairs of oval traps (Promar 'large' 81 x 50 x 30cm `(1 cm mesh size

106 and $12 \mathrm{~cm}$ minimum tunnel diameter $)$ and 'extra-large' $91 \times 62 \times 50 \mathrm{~cm}(2.5 \mathrm{~cm}$ mesh and $15 \mathrm{~cm}$

107 tunnel diameter)) were positioned approximately $2 \mathrm{~m}$ from one another with trap entrances

108 positioned parallel with the shoreline. The distance that the traps were positioned from shore was

109 dictated by the slope of the shoreline; in order to avoid drowning concurrently caught turtles. The

110 traps were positioned such that a small portion of trap protruded from the surface. Each site used

111 two 'large' traps during the 2006 sampling season. During the 2007 and 2008 sampling season

112 each site had one 'large' and one 'extra-large' trap. 'Extra-large' traps were introduced during

1132007 and 2008 to ensure that we were not excluding larger bluegills and thus validate the 2006

114 size data. Trapping sites were located at approximately equal intervals around the periphery

115 (littoral zone) of each reservoir. Upon arriving at the pre-determined trapping location, the exact

116 positioning of the traps was again dictated by the slope of the shoreline. Each trap was baited

117 with commercially available dip bait (Premo brand 'original super-sticky dip bait') hung inside

118 the trap in a cheesecloth bag and positioned in as flat a position as the shoreline allowed in order

119 to keep turtles and fish from getting under the trap or causing the trap to shift into deeper water.

120 We checked traps every 24 hours for five days and recorded species and standard length of all

121 fish and then released them immediately.

122 Analysis

123 We determined the transitional zone area and the size of the riverine and lacustrine zones

124 a posteriori for each reservoir and each year. We defined the transitional zone as the area of the

125 reservoir where the presence of thermal stratification fluctuated due to weather conditions (wind

126 and flooding) during the sampling period. Therefore, the transitional zone begins at the point

127 when a well-mixed epilimnion and a metalimnion are present outside of the thalweg (if present)

128 and continues until underflows terminate into interflows through the metalimnion (Figure 1).

129 Length and catch frequency (the total number of fish caught during a five-day period for

130 each site) could not be normalized for all groups, so comparisons among reservoir zones (i.e.

131 within each reservoir) were conducted using Kruskal-Wallis tests and a priori Mann-Whitney U

132 tests. The same tests were used when comparing catch frequency among reservoir zones for all

133 reservoirs combined, but one-way ANOVA with post-hoc Tukey tests were employed to compare

134 the standard length among zones for all reservoirs combined. Although the length data were not

135 normal, ANOVA is robust for non-parametric data at sample sizes of 30 or greater for each group 
136 when the model is balanced. For our unbalanced model, normality can generally be assumed at

137 sample sizes greater than 100 per group and our sample sizes are approximately 300 per group.

138 We compared the catch frequency of small vs. large bluegills among reservoir zones for the

139 pooled data (all reservoirs combined) using a two sample Kolmogorov-Smirnov test. All

140 statistics were performed using SPSS 12.0

\section{Results}

\section{Standard length}

143 Standard length only varied by reservoir zone for Dow Lake during 2006. In that case,

144 bluegill caught in the transitional zone were smaller than those caught in the other zones

145 (riverine: Mann-Whitney, $U=412, p=0.019$; lacustrine: $U=431.5, p=0.004$ ), but this result was not

146 seen during 2007 (Figure 3). When the length data from all reservoirs was combined, there were

147 no differences among zones (one-way ANOVA, $\mathrm{F}_{(2,822)}=0.053, \mathrm{p}=0.921$ ).

148 Catch frequency

149 There was no difference in the catch frequency of bluegill among reservoir zones for any

150 of the reservoirs (Table 2). Catch frequency did not vary among reservoir zones when the data

151 from all reservoirs was pooled either (Kruskal-Wallis, $\chi^{2}=1.094, p=0.579$ ). Because the

152 distribution of lengths was bimodal for all reservoirs in all years, we split the dataset at the saddle

153 of the distribution $(>/<8.5 \mathrm{~cm}$, Figure 4) and asked if the number of small or large bluegills

154 varied over reservoir zone for each reservoir. Only in Lake Hope were small bluegills

155 encountered more often in the transitional zone than in the fluvial zone during 2008 (Mann-

156 Whitney, $U=357, p=0.019$, Figure 5), but this result was not observed during the previous year.

157 Combined for all reservoirs, there was no difference in the catch frequency of both small and

158 large bluegills among zones (Kruskal-Wallis; small: $\chi^{2}=2.285, \mathrm{p}=0.319$; large: $\chi^{2}=0.406$,

$159 \mathrm{p}=0.816$ ). Additionally, there was no relationship between the catch frequency of small vs. large

160 bluegills among reservoir zones (Kolmogorov-Smirnov, $Z=1.083, \mathrm{p}=0.192$ ).

\section{Discussion}

162 Bluegill populations are influenced by a variety of factors including both abiotic factors

163 such as turbidity (Stein et al, 1995) or temperature (Wilhaber and Lamberson, 2004) and biotic

164 factors such as prey availability (Garvey and Stein, 1998; Hoxmeier et al, 2009) or predators

165 (Werner and Hall, 1988); all of these factors vary dramatically among reservoir zones as a simple

166 function of stratification regime (as well as other factors such as nutrient loading, water retention 
167 time, etc) (Kimmel et al, 1990). However, few differences in bluegill among reservoir zones

168 were observed in our study. Size of bluegill differed among zones at Dow Lake during 2006, but

169 this result was not observed during 2007. Similarly, small bluegills were caught more frequently

170 in the transitional zone at Lake Hope during 2008, but not during 2007. When the data from all

171 reservoirs was pooled, there were no differences in either size or catch frequency among reservoir

172 zones, suggesting that habitat partitioning may be based on different criteria in reservoirs

173 (Gelwick and Matthews, 1990; Eggleton et al, 2005) than has previously been described for

174 natural lakes (e.g. Werner et al, 1977).

175 The lack of repeatability in our findings among years may be indicative of the true nature

176 of reservoirs as a habitat for bluegill. Resources and conditions within a reservoir may be

177 dependent on prevailing weather patterns (Lienesch and Matthews, 2000; but see Edwards et al

178 2007), inputs from the watershed (Gido et al, 2002; Vanni et al, 2005) and presence of certain

179 species (e.g. gizzard shad; Vanni et al, 2005). All of these variables can fluctuate dramatically

180 year to year and cause shifts in prey availability (Betsill and VanDenAvyle, 1994) and predation

181 intensity (Jackson and Noble, 2000). Additionally, the artificial, managed nature of reservoirs

182 creates dynamics environments where water levels and habitat availability/suitability

183 (Collingsworth and Kohler, 2010) and stocking of competitors (Leonard et al, 2010) and/or

184 predators may vary yearly. Therefore, while size and catch frequency of bluegill may differ by

185 reservoir zone at times (as we observed at Dow during 2006 and Hope during 2008), they are

186 likely influenced by other factors as well, which may have disrupted our ability to consistently

187 detect differences among zones.

188 Bluegill spawning behavior also may influence the detectability of differences in length

189 and catch frequency among reservoir zones (if they exist). Bluegill spawning is condition-

190 dependent for males (males in better physical condition spawn first; Cargnelli and Neff, 2006),

191 which results in protracted spawning (spawning over an extended period; Kaemingk et al., 2014).

192 Given the differences in prey availability among reservoir zones (Betsill and VanDenAvyle,

193 1994), protracted spawning may be more prevalent in reservoirs than in lakes and could cause

194 behavioral plasticity in habitat use that is difficult to detect using standard techniques (e.g.

195 trapping, netting, or electro-shocking). That is, if bluegill spawning occurs over a wider range of

196 times in reservoirs, population wide shifts in habitat use would be similarly spread over a longer

197 duration and differences among zones, which may be important to bluegill, may also be difficult

198 to detect. This is supported by Jolley et al (2009), who found that the timing of spawning in

199 bluegill varied among nearby reservoirs and among years in the same reservoirs 
The size structure of the bluegills we caught by trapping (all reservoirs combined) was

201 bimodal and somewhat positively skewed. The positive skew was determined by the uniformly

202 smaller bluegill that freely travel through the traps without being caught while the right tail

203 extends because larger individuals are rare. The saddle in the size distribution at approximately

$2048.5 \mathrm{~cm}$ is more intriguing. Bluegills $<10 \mathrm{~cm}$ (except planktivorous larvae) are normally found in

205 the littoral zone of lakes because this area provides the greatest protection from predation

206 (Werner and Hall, 1979). It may be that in our study, bluegill move away from the shoreline

207 reservoir-wide at a much smaller size in reservoirs then in natural lakes, but we believe this is

208 unlikely given the differences in 'offshore' conditions and resources among reservoir zones.

209 Likewise, it is possible that the saddle of the distribution represents two different age classes, but

210 this is also unlikely given the variation in growth rates observed in bluegills among reservoirs

211 (Jackson et al, 2008) and their protracted spawning behavior. More likely, the saddle is a result

212 of size selective predation by largemouth bass (Olson, 1996) or other piscivores such as saugeye.

213 Because these piscivores are gape limited, bluegills over approximately $10 \mathrm{~cm}$ (Werner and Hall,

214 1979) are at lower risk of predation than smaller bluegills (Santucci and Wahl, 2003). Therefore,

215 the saddle may represent the point at which size-specific mortality of bluegill caused by predation

216 (Mittelbach and Persson, 1998) starts to decline in Southeastern Ohio reservoirs.

217 Lastly, another factor that may have contributed to our results is that our methodology did

218 not detect temporal variation within a reservoir. Because trapping occurred during the course of a

219 few weeks for each reservoir, differences in catch frequency or size among zones as a result of

220 behavioral plasticity during ontogeny may be diluted. However, Gelwick and Matthews (1990)

221 suggest that there is little temporal variation in littoral fish assemblages of reservoirs relative to

222 lakes because these assemblages are 'evolutionarily short-lived'. That is, because a given

223 reservoir has not existed long in evolutionary time, fish assemblages may not exhibit the same

224 patterns seen in natural lakes which have existed for many years. Our results seem to support this

225 conclusion given that we only saw differences in the oldest of the reservoirs we sampled.

226 Similarly, anthropogenic factors such as intensive stocking (Gelwick and Matthews, 1990) or the

227 maintenance of a community dominated by a small number of species (Eggleton et al, 2005) may

228 contribute to a decrease in temporal variation in habitat use in reservoirs.

229 In this study, bluegill generally did not differ in size or catch frequency among reservoir

230 zones in four Southeastern Ohio reservoirs. This result, although unexpected due to the broad

231 differences in habitat characteristics among reservoir zones, may be caused by a combination of

232 factors including prey availability relative to predation intensity in reservoirs, management 
233 practices, limnology, and assemblage complexity. Kaemingk et al (2014), working with limnetic 234 bluegills, hypothesized that similar factors may regulate the timing and duration of spawning 235 behavior, which should have reinforced differences in bluegill abundance among reservoir zones. 236 Despite the fact that significant differences were found using the same approach with aquatic 237 turtles (Ruhl, 2013b), we did not detect differences in bluegill size or catch frequency among 238 zones. Thus, it is likely that a categorical (functional zone) approach to detecting differences in 239 bluegill ecology within a reservoir is not appropriate. 


\section{Acknowledgments}

241 We wish to thank all of the undergraduate assistants who participated in sampling, the members

242 of the Roosenburg lab for their helpful suggestions, and Drs. Warren JS Currie and K Cuddington

243 for their assistance. Two anonymous reviewers provided comments that improved an earlier

244 version of this manuscript. 


\section{Bibliography}

246 Aday DD, Hoxmeier JH, Wahl DH. 2003. Direct and indirect effects of gizzard shad o bluegill

247 growth and population size structure. Transactions of the Americans Fisheries Society, 132, 4724856.

249 Bernot RJ, Dodds WK, Quist MC, and Guy CS. 2004. Spatial and temporal variability of 250 zooplankton in a great plains reservoir. Hydrobologia, 525:1-3, 101-112.

251 Betsill RK and VanDenAvyle MJ. 1994. Spatial heterogeneity of reservoir zooplankton - a 252 matter of timing. Hydrobiologia, 277:1, 63-70.

253 Cargnelli LM and Neff BD. 2006. Condition-dependent nesting in bluegill sunfish Lepomis 254 macrochirus. Journal of Animal Ecology, 75:3, 627-633.

255 Collingsworth PD and Kohler CC. 2010. Abundance and habitat use of juvenile sunfish among 256 different macrophyte stands. Lake and Reservoir Management, 26:1, 35-42.

257 Edwards KR, Phelps QE, Graeb BDS, and Willis DW. 2007. Asynchronous bluegill recruitment 258 in four South Dakota impoundments. Journal of Freshwater Ecology, 22:1, 19-22.

259 Eggleton MA, Ramirez R, Hargrace CW, Gido KB, Masoner JR, Schnell GD, and Matthews WJ. 260 2005. Predictability of littoral-zone fish communities through ontogeny in Lake Texoma, 261 Oklahoma-Texas, USA. Environmental Biology of Fishes, 73:1, 21-36.

262 Garvey JE and Stein RA. 1998. Competition between larval fishes in reservoirs: The role of 263 relative timing of appearance. Transactions of the American Fisheries Society, 127:6, 10212641039.

265 Garvey JE, Herra TP, and Leggett WC. 2002. Protracted reproduction in sunfish: The temporal 266 dimension in fish recruitment revisited. Ecological Applications, 12:1, 194-205. 
267 Gelwick FP and Matthews WJ. 1990. Temporal and spatial patterns in the littoral-zone fish 268 assemblages of a reservoir (Lake Texoma, Oklahoma-Texas, USA. Environmental Biology of 269 Fishes, 27:2, 107-120.

270 Gido KB, Hargrave CW, Matthews WJ, Schnell GD, Pogue DW and Sewell GW. 2002.

271 Structure of littoral-zone fish communities in relation to habitat, physical, and chemical gradients 272 in a southern reservoir. Environmental Biology of Fishes, 63:3, 253-263.

273 Hoxmeier JH, Aday DD, and Wahl DH. 2009. Examining interpopulation variation in bluegill 274 growth rates and size structure: effects of harvest, maturation, and environmental variables.

275 Transactions of the American Fisheries Society, 138:2, 423-432.

276 Jackson JR and Noble RL. 2000. Relationships between annual variations in reservoir 277 conditions and age-0 largemouth bass year-class strength. Transactions of the American 278 Fisheries Society, 129:3, 699-715.

279 Jackson ZJ, Quist MC, and Larscheid JG. 2008. Growth standards for nine North American fish 280 species. Fisheries Management and Ecology, 15:2, 107-118.

281 Jolley JC, Edwards KR, and Willis DW. 2009. Bluegill (Lepomis macrochirus) spawning 282 periodicity and hatching duration in the Northern great plains, USA. Journal of Freshwater 283 Ecology, 24:1, 29-38.

284 Kaemingk MA, Stahr KJ, Jolley JC, Holland RS, and Willis DW. 2014. Evidence for bluegill 285 spawning plasticity obtained by disentangling complex factors related to recruitment. Canadian 286 Journal of Fisheries and Aquatic Sciences, 71:1, 93-105.

287 Kennedy RH and Walker WW. 1990. Reservoir Nutrient Dynamics. In Thornton 288 KW, Kimmel BL, and Payne FE (eds.), Reservoir Limnology: Ecological Perspectives, pp. 109289 131. John Wiley and Sons, New York, NY 
290 Kimmel BL, Lind OT, and Paulson LJ. 1990. Reservoir primary production. In Thorton KW,

291 Kimmel BL, and Payne FE (eds.), Reservoir Limnology: Ecological Perspectives, pp. 133-194.

292 John Wiley and Sons, New York, NY

293 Leonard DM, DeVries DR, and Wright RA. 2010. Investigating Interactions between Channel 294 Catfish and Other Sport Fishes in Small Impoundments. North American Journal of Fisheries 295 Management, 30:3, 732-741

296 Lienesch PW and Matthews MJ. 2000. Daily fish and zooplankton abundances in the littoral 297 zone of Lake Texoma, Oklahoma-Texas, in relation to abiotic variables. Environmental Biology 298 of Fishes, 59:3, 271-283.

299 Michaletz PH. 2006. Prey resource use by bluegill and channel catfish in small impoundments. 300 Fisheries Management and Ecology. 13, 347-354.

301 Mittelbach GG. 1981. Foraging efficiency and body size - a study of optimal diet and habitat 302 use by bluegills. Ecology, 62:5, 1370-1386.

303 Mittelbach GG and Persson L. 1998. The ontogeny of piscivory and its ecological 304 consequences. Canadian Journal of Fisheries and Aquatic Sciences, 55:6, 1454-1465.

305 Newbrey MG, Bozek MA, Jennings MJ, and Cook JE. 2005. Branching complexity and 306 morphological characteristics of coarse woody structure as lacustrine fish habitat. Canadian 307 Journal of Fisheries and Aquatic Sciences, 62:9, 2110-2123.

308 Olson MH. 1996. Predator-prey interactions in size-structured fish communities: Implications of 309 prey growth. Oecologia, 108:4, 757-763.

310 Partridge DG and DeVries DR. 1999. Regulation of growth and mortality in larval bluegills:

311 implications for juvenile recruitment. Transactions of the American Fisheries Society, 128:4, $312625-638$. 
313 Ruhl N. 2013a. The lotic-lentic gradient in reservoirs and estuaries. In: Ruhl N, The lotic-lentic 314 gradient in reservoirs and estuaries, Ohio University Dissertation.

315 Ruhl N. 2013b. Spatial, temporal, and sex-dependent differences in eastern musk turtle 316 (Sternotherus odoratus) size and catch frequency in a Southeastern Ohio reservoir. In: Ruhl N, 317 The lotic-lentic gradient in reservoirs and estuaries, Ohio University Dissertation.

318 Santucci VJ and Wahl DH. 2003. The effects of growth, predation, and first-winter mortality on 319 recruitment of bluegill cohorts. Transactions of the American Fisheries Society, 132:2, 346-360.

320 Shoup DE, Callahan SP, Wahl DH, Peirce CL. 2007. Size-specific growth of bluegill, 321 largemouth bass and channel catfish in relation to prey availability and limnological variables. 322 Journal of Fish Biology. 70: 21-34.

323 Stein RA, DeVries DR, and Dettmers JM. 1995. Food-web regulation by a planktivore: 324 Exploring the generality of the trophic cascade hypothesis. Canadian Journal of Fisheries and 325 Aquatic Sciences, 52:11, 2518-2526.

326 Theel HJ and Dibble ED. 2008. An experimental simulation of exotic aquatic macrophyte 327 invasion and its influence on foraging behavior of bluegill. Journal of Freshwater Ecology, 23:1, $32879-89$.

329 Thornton K. W. 1990. Sedimentary processes. In Thornton KW, Kimmel BL, and Payne FE 330 (eds.), Reservoir Limnology: Ecological Perspectives, pp. 43-70. John Wiley and Sons, New 331 York, NY

332 Tomcko CM and Pierce RB. 2001. The relationship of bluegill growth, lake morphometry, and 333 water quality in Minnesota. Transactions of the American Fisheries Society, 130:2, 317-321.

334 Tomcko CM and Pierce RB. 2005. Bluegill recruitment, growth, population size structure, and 335 associated factors in Minnesota Lakes. North American Journal of Fisheries Management. 25: 336 171-179. 
337 Vanni MJ, Arend KK, Bremigan MT, Bunnell DB, Garvey JE, Gonzalez MJ, Renwick WH, 338 Soranno PA, and Stein RA. 2005. Linking landscapes and food webs: Effects of omnivorous 339 fish and watersheds on reservoir ecosystems. Bioscience, 55:2, 155-167.

340 Werner RG. 1969. Ecology of limnetic bluegill (Lepomis macrochirus) fry in Crane Lake

341 Indiana. American Midland Naturalist, 81:1, 164-181.

342 Werner EE, Hall DJ, Laughlin DR, Wagner DJ, Wilsmann LA, and Funk FC. 1977. Habitat 343 partitioning in a freshwater fish community. Journal of the Fisheries Research Board of Canada, $344 \quad 43: 3,360-370$.

345 Werner EE and Hall DJ. 1979. Foraging efficiency and habitat switching in competing 346 sunfishes. Ecological Society of America, 60:2, 256-264.

347 Werner EE and Hall DJ. 1988. Ontogenetic habitat shifts in bluegill: The foraging rate-predation 348 risk trade-off. Ecological Society of America, 69:5, 1352-1366.

349 Werner EE and Peacor SD. 2003. A review of trait-mediated indirect interactions in ecological 350 communities. Ecology, 84:5, 1083-1100.

351 Wildhaber ML and Lamberson PJ. 2004. Importance of the habitat choice behavior assumed 352 when modeling the effects of food and temperature on fish populations. Ecological Modeling. 353 175: 395-409. 


\section{Figure 1}

Diagram of vertical and horizontal zonation in a stereotypical reservoir

The curve ending in $4^{0} \mathrm{C}$ represents a stereotypical summer thermocline in a deep reservoir.

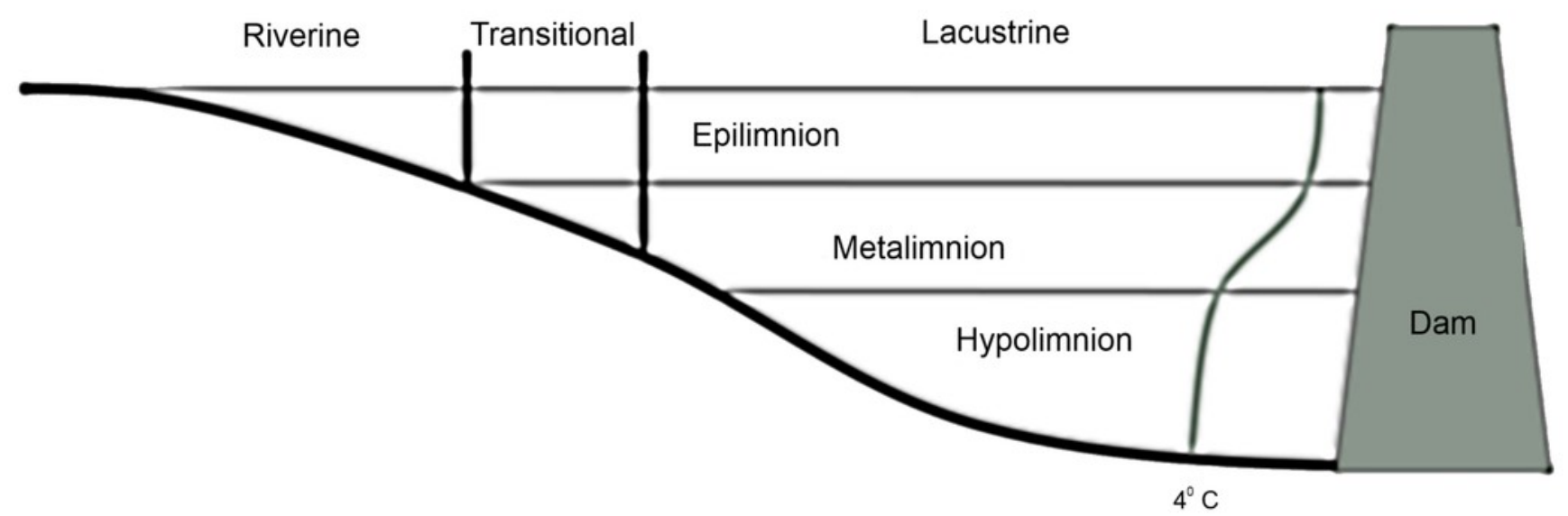




\section{Figure 2}

County map of Ohio highlighting the counties where trapping occurred

Figure 2. County map of Ohio highlighting the counties where trapping occurred (gray shading; Vinton and Athens) and location of the reservoirs (asterisks). The bold line indicates the extent of glaciation. 


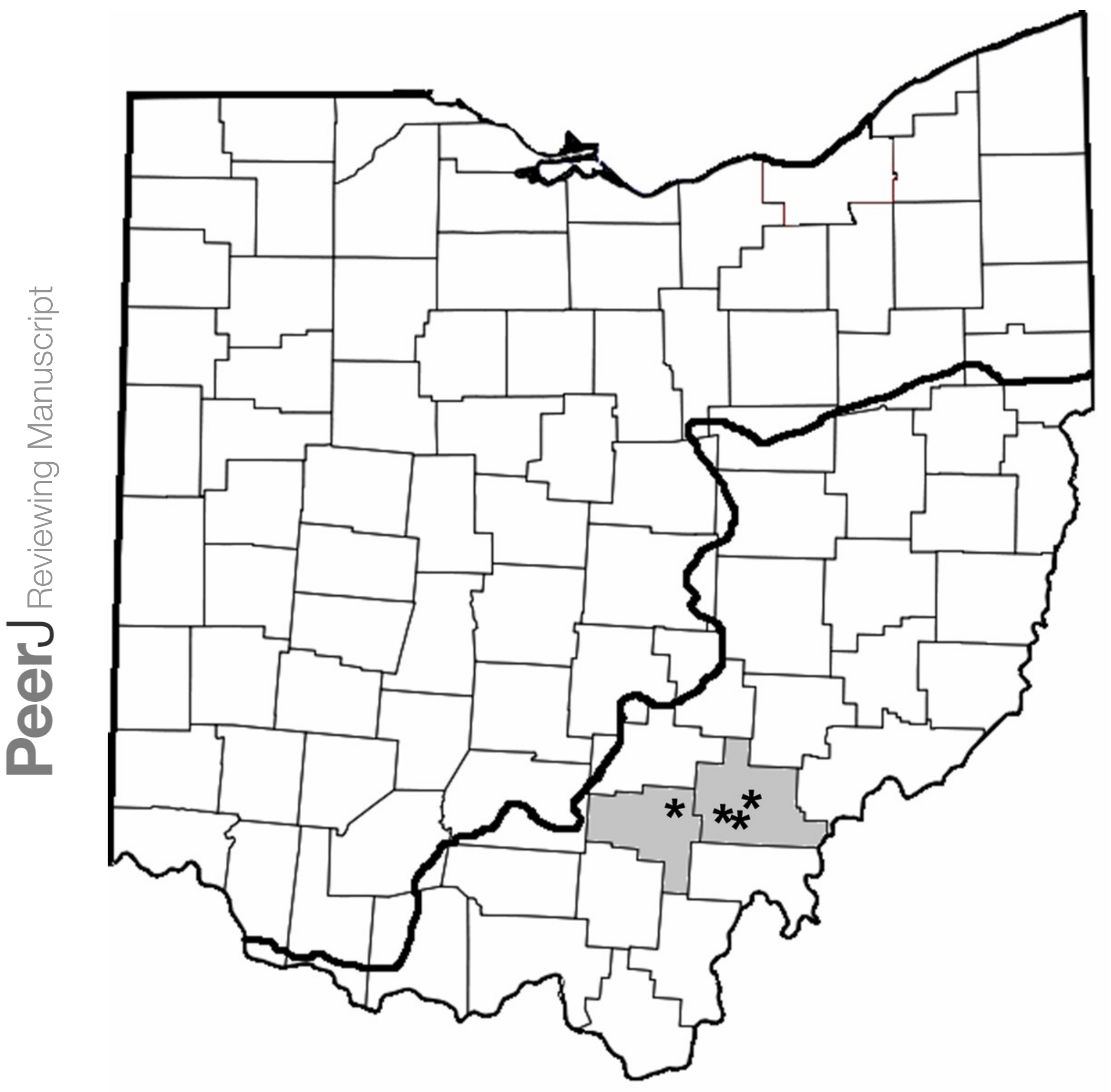




\section{Figure 3}

Box-plot of bluegill standard length

Figure 3. Box-plot of bluegill standard length between zones at Dow Lake during 2006 and 2007. Bluegills caught in the transitional zone during 2006 were significantly smaller than those caught in the riverine (Mann-Whitney, $U=412, p=0.019)$ or lacustrine $(U=431.500$, $\mathrm{p}=0.004$ ) zones, but this result was not observed during 2007. Box represents first and third quartiles, whiskers positioned at $+/-2 \mathrm{SD}$, horizontal line is the mean. 


\section{Figure 4}

Histogram of bluegill standard lengths

Figure 4. Histogram of bluegill standard lengths for all reservoirs combined. The dashed line indicates the saddle in the distribution at $8.5 \mathrm{~cm}$ where the data was bifurcated into "small" and "large".

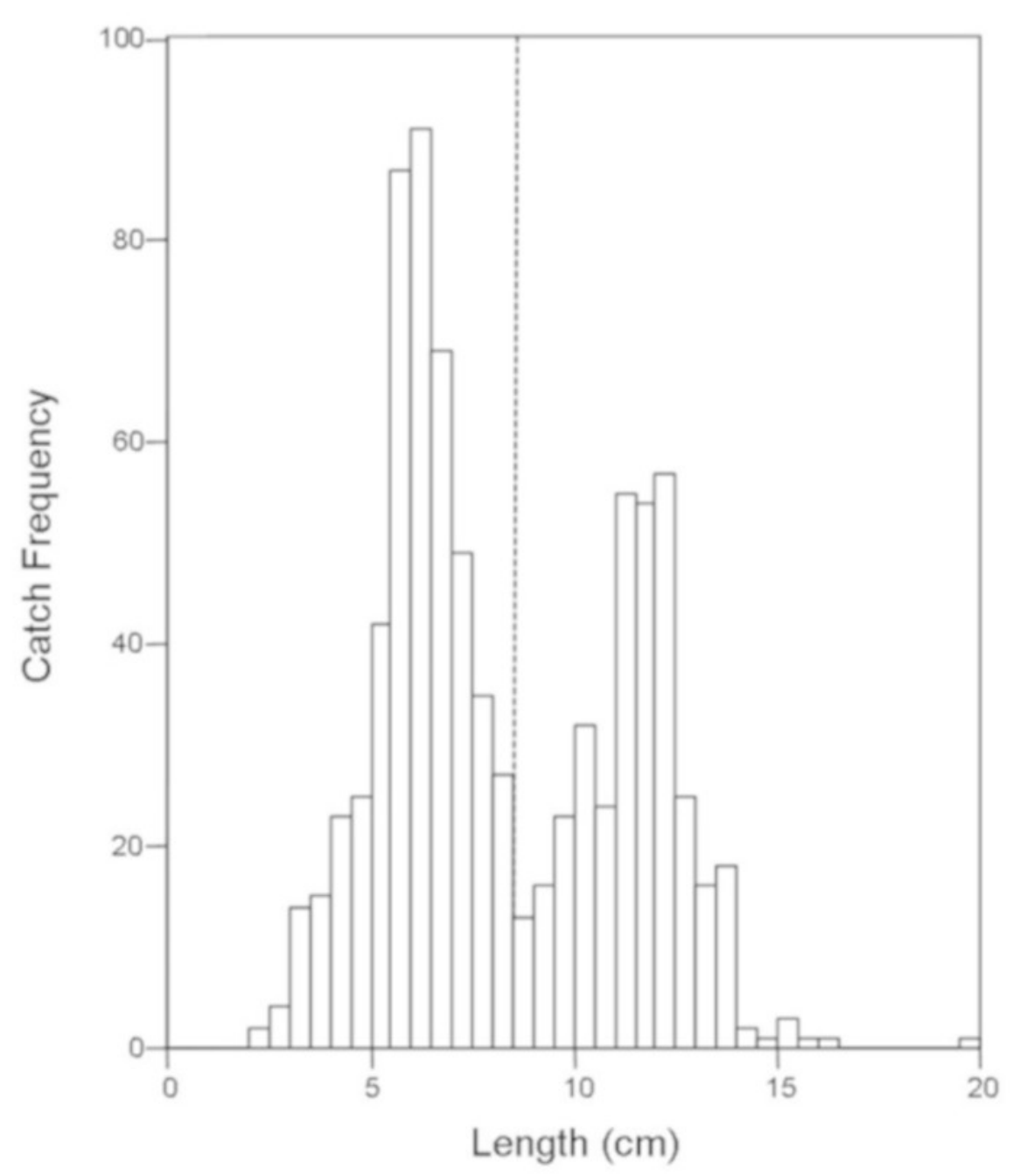




\section{Figure 5}

Catch frequency of small bluegills between zones in 2007 and 2008 at Lake Hope.

Figure 5. Box-plot of catch frequency of small bluegills $(<8.5 \mathrm{~cm})$ among zones during 2007 and 2008 at Lake Hope. Catch frequency in the riverine zone was significantly lower than in the transitional zone in 2008 (Mann-Whitney, $U=357, p=0.019$ ), but there were no significant difference among zones in 2007. Box represents first and third quartiles, whiskers positioned at $+/-2 \mathrm{SD}$, horizontal line is the mean. 


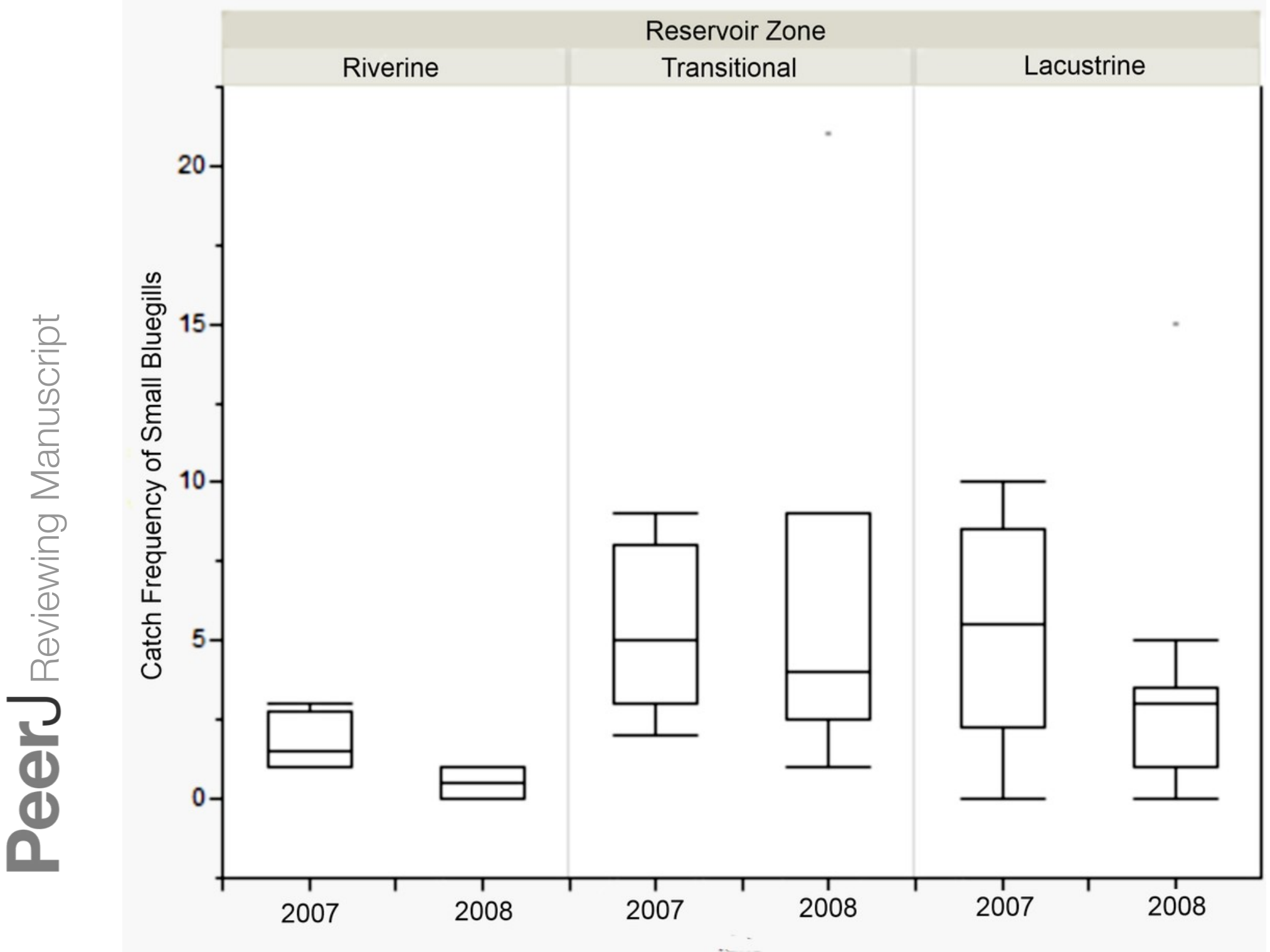




\title{
Table $\mathbf{1}_{\text {(on next page) }}$
}

Basin Morphometrics, Fill Date, and Date of last Bluegill Stocking for Each Reservoir

\author{
Basin Morphometrics, Fill Date, and Date of last Bluegill Stocking for Each Reservoir
}


Table 1

Basin Morphometrics, Fill Date, and Date of last Bluegill Stocking for Each Reservoir

\begin{tabular}{lrrrr}
\hline Variable & Dow & Fox & Hope & Snowden \\
\hline Catchment Area $\left(\mathrm{km}^{2}\right)$ & 18.90 & 10.36 & 25.64 & 9.78 \\
Surface Area $\left(\mathrm{km}^{2}\right)$ & 0.67 & 0.23 & 0.48 & 0.65 \\
Maximum Depth $(\mathrm{m})$ & 9.5 & 6.0 & 6.5 & 10.0 \\
Mean Depth (m) & 1.62 & 1.28 & 1.31 & 2.45 \\
Volume $\left(\mathrm{m}^{3}\right)$ & 1085069 & 294975 & 630744 & 1590558 \\
Shoreline Length (km) & 11.27 & 3.86 & 9.18 & 11.91 \\
Shoreline Development & 5.49 & 3.21 & 5.29 & 5.89 \\
Maximum Fetch (km) & 2.00 & 0.71 & 1.07 & 2.87 \\
Fill Date & 1960 & 1968 & 1939 & 1970 \\
Last Stocked with Bluegill & 1972 & $N / A$ & 1979 & 1970 \\
\hline
\end{tabular}




\section{Table 2 (on next page)}

Summary of the Number of Sampling Sites and the Total Catch for Each Reservoir, Zone, and Year that Sampling Occurred.

Summary of the Number of Sampling Sites and the Total Catch for Each Reservoir, Zone, and Year that Sampling Occurred. 
Table 2

Summary of the Number of Sampling Sites and the Total Catch for Each Reservoir, Zone, and Year that Sampling Occurred.

\begin{tabular}{lrrr}
\hline Reservoir/Year & Zone & \#Sites & Total Catch \\
\hline \multirow{2}{*}{ Dow 2006 } & Riverine & 4 & 57 \\
& Transitional & 4 & 22 \\
& Lacustrine & 8 & 67 \\
\hline \multirow{2}{*}{ Fox 2006 } & Riverine & 5 & 72 \\
& Transitional & 2 & 19 \\
& Lacustrine & 2 & 27 \\
\hline \multirow{2}{*}{ Dow 2007 } & Riverine & 17 & 104 \\
& Transitional & 11 & 103 \\
& Lacustrine & 12 & 92 \\
\hline \multirow{2}{*}{ Hope 2007 } & Riverine & 4 & 31 \\
& Transitional & 5 & 47 \\
& Lacustrine & 6 & 60 \\
\hline \multirow{2}{*}{ Snowden 2007 } & Riverine & 3 & 25 \\
& Transitional & 6 & 59 \\
& Lacustrine & 7 & 40 \\
\hline \multirow{2}{*}{ Hope 2008 } & Riverine & 4 & 19 \\
& Transitional & 6 & 47 \\
& Lacustrine & 10 & 43 \\
\hline
\end{tabular}

Note: raw data were used for statistical analysis (not the means presented here). 


\section{Table 3 (on next page)}

Results of a Kruskal-Wallis Analysis of Catch Frequency among Reservoir Zones for Each Reservoir and Year

Results of a Kruskal-Wallis Analysis of Catch Frequency among Reservoir Zones for Each Reservoir and Year 
Table 3

Results of a Kruskal-Wallis Analysis of Catch Frequency between Reservoir Zones for Each Reservoir and Year

\begin{tabular}{lccc}
\hline Lake & Year & $\chi^{2}$ & p-value \\
\hline Fox & 2006 & 2.881 & 0.237 \\
Dow & 2006 & 5.094 & 0.078 \\
Dow & 2007 & 0.550 & 0.760 \\
Snowden & 2007 & 0.793 & 0.673 \\
Hope & 2007 & 0.812 & 0.666 \\
Hope & 2008 & 1.832 & 0.400 \\
\hline
\end{tabular}

